\title{
Population Fluctuations of the Muskrat in Coastal Northern Sweden
}

\author{
Kjell DANELL
}

\begin{abstract}
Danell K. 1985: Population fluctuations of the muskrat in coastal northern Sweden. Acta theriol., 30, 12: 219-227 [With 1 Table \& 3 Figs.]

The fluctuations of five muskrat populations in coastal northern Sweden are described over periods of $7-14$ years. The population in Sladan was studied more intensively since it colonized this area around 1963. During the last 14 years it fluctuated with a periodicity of 4 years. This time length is identical to the vole cycle length in the area. However, the muskrat population reached their peaks one year after the vole peaks. In the above population the predation pressure by foxes upon muskrats was recorded yearly for 9 years. The predation pressure was negatively correlated with vole density. Two other muskrat populations which settled in 1955 and 1963, respectively, displayed fluctuations similar to those of the voles, and the muskrat peaked with a one year dephasing. Two muskrat populations which had colonized their localities more recently (in 1970 and 1975) remained for some years at low levels and then steadily increased. The population fluctuations were not directly related to the changes in the vole populations.

[Department of Wildlife Ecology, Swedish University of Agricultural Sciences, S-901 83 Umeå, Sweden]
\end{abstract}

\section{INTRODUCTION}

The muskrat Ondatra zibethica (Linnaeus, 1766) is native in the wetlands of North America. It was introduced into central Europe in 1905 and has thereafter spread, or been introduced, into many countries in Europe and Asia (e.g., Ulbrich, 1930; Hoffmann, 1958). This microtine rodent invaded northern Sweden from Finland around 1950 and is continuing its spread southwards. As the muskrat in Sweden has a low value as a game and is not causing any extensive damage, hunting and trapping is negligible. They are therefore suitable for populations studies of the species within its new range in northern Europe.

During a previous study of a muskrat population in a shallow lake (Sladan) in northern Sweden I found that (1) the size of the autumn population varied considerably between years, (2) the peak of the muskrat population followed one year after the peak in the vole (Microtus and Clethrionomys) populations and (3) there were high predation losses of young muskrat litters during years with low densities of voles, and low predation losses during years when the voles were abundant (Danell, 1978a). As the main predator was the red fox Vulpes vulpes (Linnaeus, 
1758) I suggested a "vole-fox-muskrat" relationship. Further, as the voles in northern Sweden show a 3-4 year cycle in numbers (e.g., Hörnfeldt, 1978) it may lead to muskrat fluctuations of the same periodicity.

This contrasts with reports from North America, where fluctuating muskrat populations show a periodicity of 4-6 years (McLeod, 1948, 1950; Butler, 1962) or 10 years (Elton \& Nicholson, 1942; Errington, 1963; Bulmer, 1974).

In order to examine the "vole-fox-muskrat" hypothesis further I have continued the detailed population study at Sladan lake for another three years and thus included a second vole cycle. As changes in vole numbers are synchronous over large geographic areas in northern Sweden we may expect that if the "vole-fox-muskrat" relation is a general phenomenon, many populations should exhibit fluctuations with a more or less synchronic 3-4 year periodicity. Therefore, I have during the past $7-12$ years studied four other muskrat populations on areas colonized for longer (since 1955 and 1963) or shorter (since 1970 and 1975) periods of time.

\section{METHODS}

Five muskrat populations were studied in the coastal area of northern Sweden. The geographic position and the area of the investigated sites as well as the approximate year of the muskrat colonization are given in Table 1. The localities

Table 1

Geographic position, area and approximate year of muskrat colonization for the studied muskrat localities.

\begin{tabular}{lccc}
\hline Locality name & Geographic position & $\begin{array}{c}\text { Area, } \\
\text { hectares }\end{array}$ & $\begin{array}{c}\text { Approximate year of } \\
\text { colonization by } \\
\text { muskrats }\end{array}$ \\
\hline Lampen & $65^{\circ} 48^{\prime} \mathrm{N}, 23^{\circ} 18^{\prime} \mathrm{E}$ & 65 & 1955 \\
Sladan & $65^{\circ} 55^{\prime} \mathrm{N}, 22^{\circ} 25^{\prime} \mathrm{E}$ & 80 & 1963 \\
Vitåfjärden & $65^{\circ} 56^{\prime} \mathrm{N}, 22^{\circ} 27^{\prime} \mathrm{E}$ & 145 & 1963 \\
Porsnäsfjärden & $65^{\circ} 26^{\prime} \mathrm{N}, 21^{\circ} 29^{\prime} \mathrm{E}$ & 85 & 1970 \\
Ostträsket & $64^{\circ} 55^{\prime} \mathrm{N}, 21^{\circ} 03^{\prime} \mathrm{E}$ & 170 & 1975 \\
\hline
\end{tabular}

chosen were generally shallow ones where the muskrats lived almost exclusively in houses. Further, the population estimates based on house counts are facilitated by the yearly spring flood (at snow-melt) which destroys all houses of the previous year. Building of new houses starts in May and terminates in October, when ice covers the lakes (Danell, 1978b).

The muskrat population at Sladan lake, one of the five localities, has been studied in more detail from 1972 to 1980 , by counting the muskrat houses and recording the fox attacks on houses at three times, or more, per year according to methods described by Danell (1978a). Only those cases when the fox most probably had taken the muskrat litter inside the house are regarded and used 
here as a measure on fox predation pressure on muskrats during that particular breeding season. From 1981 onwards, the frequency of house survey was reduced to once per years; in late October - early December when the ice was solid. Some of the data concerning the period up to and including 1977, although! published elsewhere (Danell, 1978a), are included here for completeness. The other four localities (Table 1) have been surveyed every year in late October - early December and numbers of inhabited houses have been counted.

The vole abundance index and the classification of vole peak years are based on data from index catches of voles carried out by Hörnfeldt (1978 and unpublished). As the populations of Clethrionomys and Microtus fluctuate synchronously the vole species are lumped together to give a "vole abundance index" (numbers of voles taken per 100 traps; $2350-2920$ traps used on three successive days and nights during the autumn each year). Further details on the survey of the microtine rodents are given by Hörnfeldt (1978).

\section{RESULTS}

The autumn muskrat population in Sladan peaked in 1974 and 1978 (Fig. 1c) and again in 1982 (Fig. 2b), while the vole numbers peaked in 1973, 1977 and 1981.

During the period of more intensive studies at Sladan (1972-1980) $0-11 \%$ of the muskrat houses were destroyed by the foxes in years with high densities of voles, while $21 \%$ or more of the houses were destroyed in years with low vole densities (Fig. 1 d \& e). There was a statistically significant negative correlation between the frequencies of houses destroyed and the vole abundance indices for the years 19721980 (Spearman's rank correlation coefficient: $r_{s}=-0.70 ; p<0.05$ ).

The two muskrat populations at two localities, Lampen $(42 \mathrm{~km}$ from Slıdan) and Vitåfjärden ( $3 \mathrm{~km}$ from Sladan), which had been occupied by muskrats since 1955 and 1963 respectively, peaked in the same years as the Sladan population (Fig. 2).

Muskrat populations at two sites only recently colonized were atypical (Fig. 3). Porsnäsfjärden ( $68 \mathrm{~km}$ from Sladan) was colonized by muskrats in 1970 and the population increased steadily to a peak in 1977, whereafter it declined continuously (Fig. 3a). The muskrat population at Ostträsket (129 $\mathrm{km}$ from Sladan) was established around 1975. Low numbers were registered up to and including 1980, whereafter the numbers have increased markedly from year to year (Fig. 3b). Both these muskrat populations did not show any obvious relationship with the vole fluctuations in the area.

\section{DISCUSSION}

The "vole-fox-muskrat" hypothesis (Danell, 1978a) was supported by data from the three localities where the muskrat had been established 
for a long time. The parallelism between the fluctuations of voles and muskrats, and the time-lag of one year between the peaks were consistent during the $2-3$ vole cycles studied. Further, the population study at the Sladan lake during the vole cycle investigated here showed similar changes in the fox predation pressure as have been reported before.

My results suggest a general 3-4 years periodicity in the muskrat fluctuation pattern at these latitudes. Thus it seems that this rodent

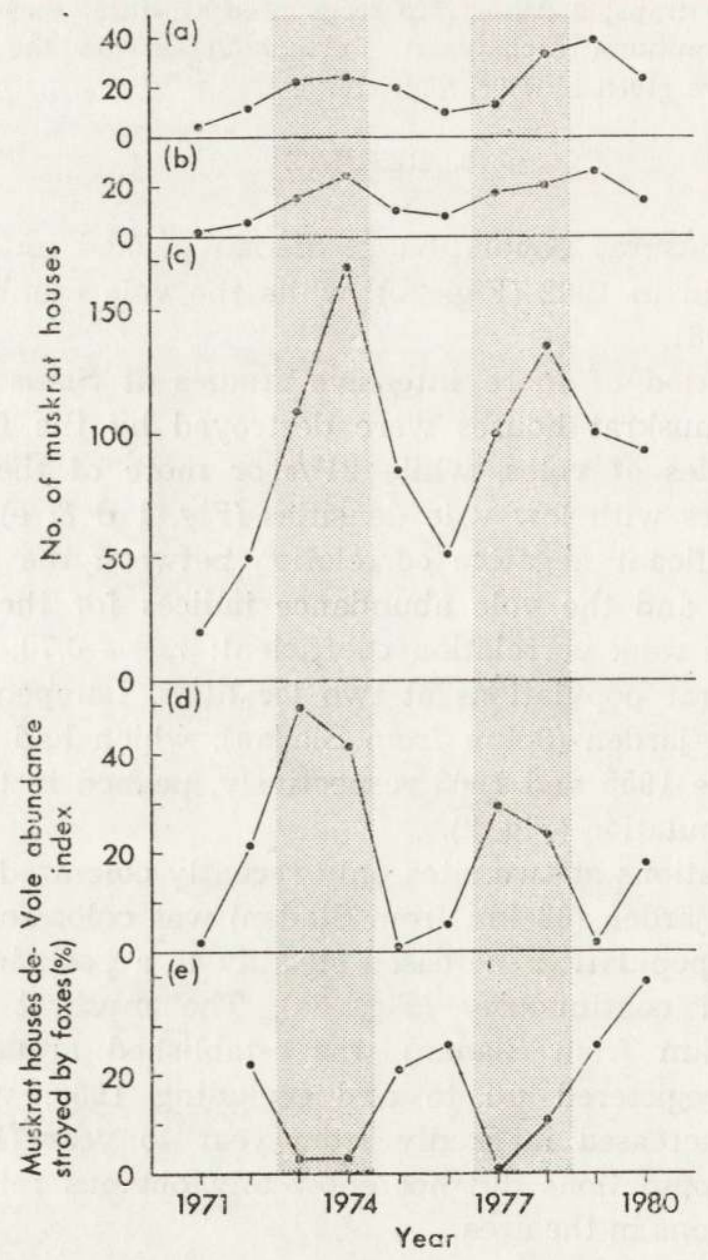

Fig. 1. Number of inhabited muskrat houses at Sladan, northern Sweden during late June (a), early August (b) and late October - early December (c), as well as the vole abundance index (d), and the frequency of muskrat houses destroyed by foxes (e). Years with high vole indices are dotted. 
exhibits fluctuations of different periodicity in different parts of its distribution range. Bulmer (1974) reanalyzed the data on fur sales in Canada and suggested that the muskrat cycle is due to predation by mink (Mustela vison Schreber, 1777), which, however, contrasts to the opinion by Errington (1943). The Canadian fur data showed that an increase in muskrats was followed by an increase in mink a year later,

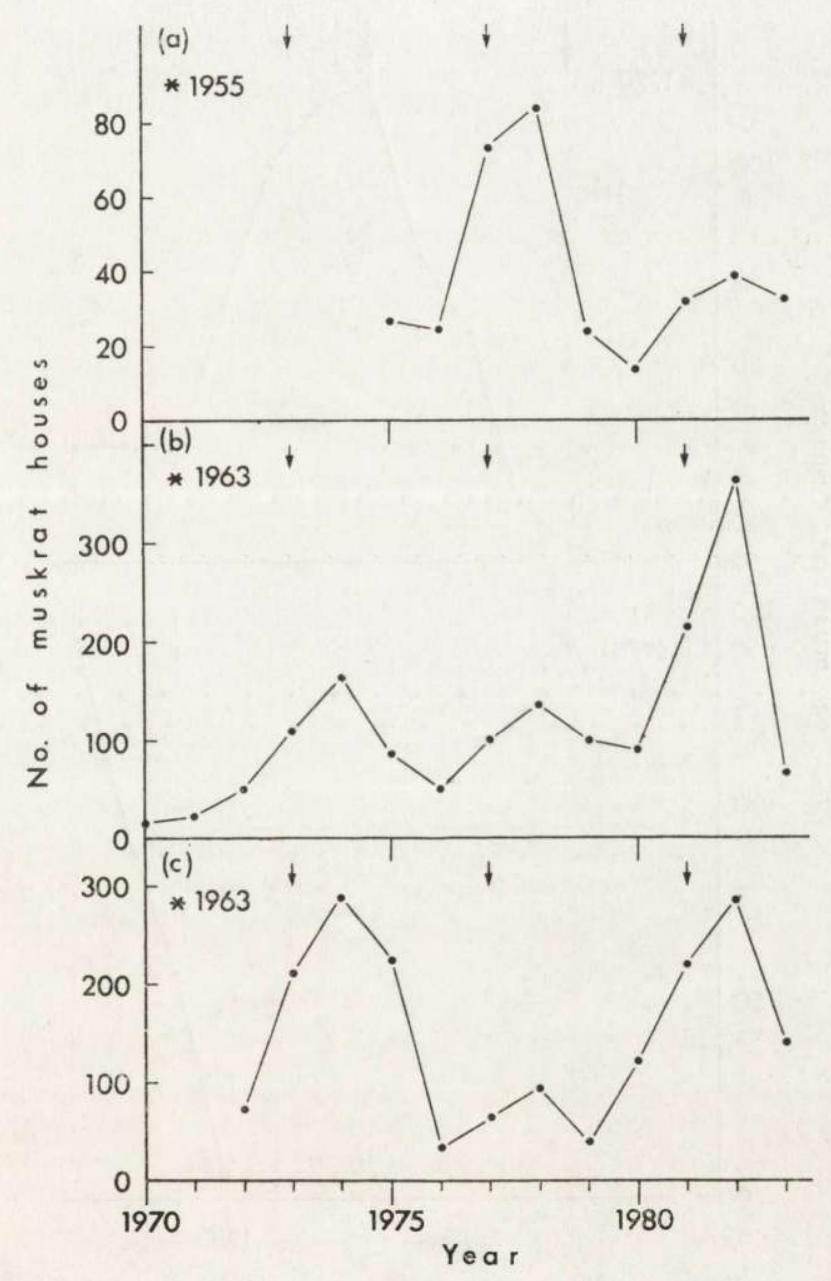

Fig. 2. Number of inhabited muskrat houses in late October - early December at Lampen (a), Sladan (6) and Vitåfjärden (c). The peak years of the vole population are marked by arrows and the approximate year of muskrat colonization is given in the upper, left corner of each figure. 
and an increase in mink was followed by a decrease in muskrats a year later (Bulmer 1974). Further analyzes demonstrated that the muskrat cycle was 2.3 years ahead of the mink cycle (Bulmer 1975). The cycles in mink might, in turn, be due to cycles in its predators, which themselves depend on snowshoe hare (Lepus americanus Erxleben, 1777) (Bulmer, 1974, 1975). In northern Sweden the muskrat is connected to

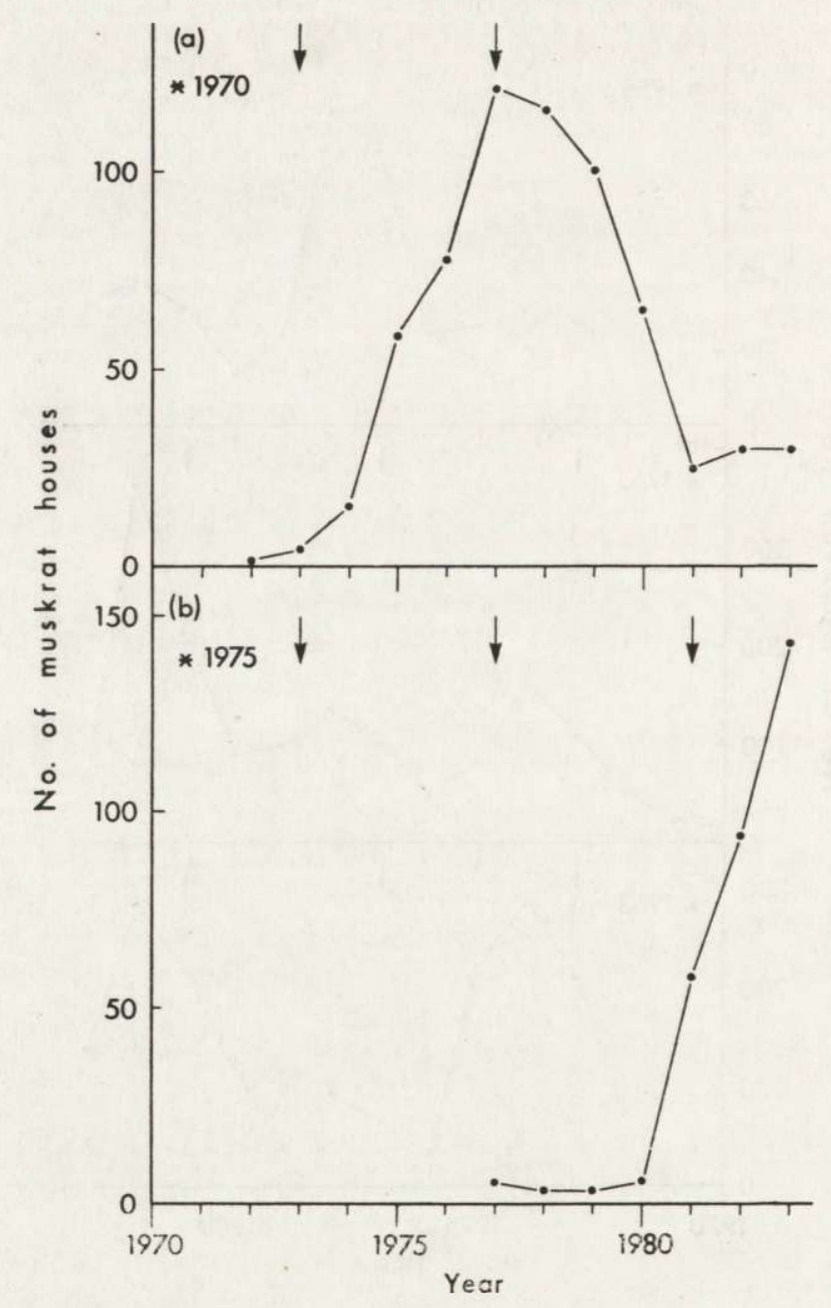

Fig. 3. Number of inhabited muskrat houses in late October - early December at Porsnäsfjärden (a) and Ostträsket (b). The peak years of the vole population are marked by arrows and the approximate year of muskrat colonization is given in the upper, left corner of each figure. 
the 3-4 year cycle of microtine rodents while in some areas of North America it thus may be connected to the 10 year cycle of snowshoe hare. The reason for the muskrat fluctuations may therefore be exogenous rather than endogenous and a predator link seems likely.

When muskrats are newly established in an area population development seems to be independent of the vole abundance. This may be explained by fox behaviour. Foxes need some time to learn how to find and catch new prey species; muskrats are more difficult to catch than voles. Further, the few muskrats during the first years in a new locality do not represent a substantial food source for foxes. However, after some years the foxes regularly search through the muskrat habitats throughout the year.

The studied localities were shallow wetlands where muskrat always construct houses, which are relatively easy for the fox to locate and take litters from. In other habitats, e.g. stream banks, muskrats construct dens and burrows and are less vulnerable to fox predation. In such areas we may expect more stable muskrat populations from year to year. However, no information from these habitats are available yet.

A reduction of the fox population in the shallow muskrat habitats may result in a lower predation pressure on muskrat litters in houses and perhaps change the muskrat population fluctuation pattern. At present, Swedish foxes are experiencing an outbreak of an epizootic sarcoptic mange. Should this epidemic drastically reduce the size of the fox population, then this will present an unparalleled opportunity for a "natural" test of the "vole-fox-muskrat" hypothesis.

Acknowledgements: I thank Olle Andersson. Hans Groth, Torbjörn Lilja and Tore Nordlund for help with the field work; Birger Hörnfeldt for use of unpublished vole data; S. C. Tapper and E. Le Boulenge for valuable comments on thel manuscript; and the National Swedish Environment Protection Board and Helge Ax: son Johnsons Stiftelse for financial support.

\section{REFERENCES}

1. Bulmer M. G., 1974: A statistical analysis of the 10-year cycle in Canada. J. Anim. Ecol., 43: 701-718.

2. Bulmer M. G., 1975: Phase relations in the ten-year cycle. J. Anim. Ecol., 44: $609-621$.

3. Butler L., 1962: Periodicities in the annual muskrat population figures fior the province of Saskatchewan. Can. J. Zool., 40: 1277-1286.

4. Danell K., 1978a: Population dynamics of the muskrat in a shallow Swedish lake. J. Anim. Ecol., 47: 697-709.

5. Danell K., 1978b: Intra- and interannual changes in habitat selection by the muskrat. J. Wildlife Manage., 42: 540-549.

6. Elton C. \& Nicholson M., 1942: Fluctuations in numbers of the muskrat (Ondatra. zibethica) in Canada. J. Anim. Ecol., 11: 96-126. 
7. Errington P. L., 1943: An analysis of mink predation upon muskrats in NorthCentral United States. Iowa Agric. Exp. Stn. Res. Bull., 320: 797-924.

8. Errington P. L., 1963: Muskrat Populations. Iowa State University Press: $1-665$. Ames.

9. Hoffmann M., 1958: Die Bisamratte. Akademische Verlagsgesellschaft Geest \& Portig K.-G.: 1-260. Leipzig.

10. Hörnfeldt B., 1978: Synchronous population fluctuations in voles, small game, owls and tularemia in northern Sweden. Oecologia (Berl.), 32: 141-152.

11. McLeod J. A., 1948: Preliminary studies on muskrat biology in Manitoba. Trans. Roy. Soc. Can., Sect. V, 42: 81-95.

12. McLeod J. A., 1950: A consideration of muskrat populations and population trends in Manitoba. Trans. Roy. Soc. Can., Sect. V, 44: 69-79.

13. Ulbrich J., 1930: Die Bisamratte. C. Heinrich: 1-137. Dresden.

Accepted, November 21, 1984.

Kjell DANELL

WAHANIA LICZEBNOSCI POPULACJI PIŻMAKA NA WYBRZEŻU POENOCNEJ SZWECJI

\section{Streszczenie}

Pięć populacji piżmaka Ondatra zibethica (Linnaeus, 1766) badano w okresie 7-14 lat (Tabela 1). Populację w Sladan badano dłużej, bo od czasu prawdopodobnej kolonizacji tego terenu w 1963 r. (Ryc. 1). W ciągu tych lat liczebność jej osiągała szczyty co 4 lata. Ten czteroletni okres jest identyczny z długością cyklu liczebności u norników na tym terenie. Jednakże faza populacyjna piżmaka przypada o rok później. Presja lisów na omawianą populację była rejestrowana przez 9 lat. Presja ta była ujemnie skorelowana $\mathrm{z}$ zagęszczeniem norników. Dwie inne populacje piżmaków, które osiedliły się w 1955 i $1963 \mathrm{r}$. zmieniały swą liczebność podobnie do norników, także z różnicą jednego roku (Ryc. 2).

Natomiast dwie pozostałe populacje, które skolonizowały swój teren w 1970 i 1975 r. pozostawały przez kilka lat na niskim, lecz stale wzrastającym poziomie liczebności. Fluktuacje liczebności nie były bezpośrednio powiązane ze zmianami w liczebności populacji norników (Ryc. 3). 